\title{
Haemostatic factors associated with vascular thrombosis in patients with systemic lupus erythematosus and the lupus anticoagulant
}

First Department of Internal Medicine, Faculty of Medicine, Krushu University, Fukuoka, Japan

T Mayumi

$K$ Nagasawa

Y Yamauchi

Y Ishii

Y Tada

Y Niho

Third Department of Internal Medicine,

Faculty of Medicine,

Kyushu University,

Fukuoka, Japan

$T$ Inoguchi

F Umeda

Correspondence to: Dr Takehito Mayumi, First Department of Internal Medicine, Faculty of Medicine, Kyushu University, Higashi-Ku,

Fukuoka 812, Japan.

Accepted for publication

4 July 1990

Takehito Mayumi, Kohei Nagasawa, Toyoshi Inoguchi, Yasuo Yamauchi, Yoshitomo Ishii, Yoshifumi Tada, Fumio Umeda, Yoshiyuki Niho

\begin{abstract}
To elucidate the mechanism of vascular thrombosis in patients with systemic lupus erythematosus and the lupus anticoagulant changes in factors associated with haemostasis were investigated. The lupus anticoagulant was associated with an increased incidence of thrombosis, particularly cerebral thrombosis. Concentrations of fibrinopeptide $A$ and fibrinopeptide $B_{815-42}$ were significantly raised in the plasma of patients with systemic lupus erythematosus and the anticoagulant compared with concentrations in patients without the lupus anticoagulant. The tendency towards formation of thrombosis was not found in all lupus patients with the anticoagulant, however. Concentrations of thromboxane $B_{2}$ were remarkably raised in the plasma of the two patients with the lupus anticoagulant who had recently had thrombosis. Concentrations of 6-keto-prostaglandin $F_{1 \alpha}$, protein $C$, antithrombin III, and plasminogen were similar in both groups. No significant decrease in serum stimulatory activity on prostacyclin production by cultured aortic endothelial cells was noted in lupus patients with the anticoagulant, but inhibition was present in the two patients with recent thrombosis. These results indicate that although patients with the lupus anticoagulant are not always in a hypercoagulable state, haemostatic abnormalities found in some patients with the anticoagulant may be predictive of thrombotic events.
\end{abstract}

The 'lupus anticoagulant' is an autoantibody against phospholipids that is recognised by prolongation of the activated partial thromboplastin time (APTT). ${ }^{1}$ The mechanism of this prolongation seems to interfere with the activation of prothrombin by the activator complex (factor Xa, V, calcium, and phospholipid). ${ }^{2}$ Patients with the lupus anticoagulant do not usually tend to bleed. ${ }^{3}$ There are reports that the lupus anticoagulant is associated with an increased tendency towards venous and arterial thrombosis. ${ }^{3-5}$ Although there are several reports on thrombosis in patients with the lupus anticoagulant, ${ }^{6-10}$ its mechanism still remains unclear. Carreras et al suggested that inhibition of prostacyclin by vascular endothelial cells might play a major part in the pathogenesis of thrombosis in some patients with the lupus anticoagulant. ${ }^{6}$ The participation of prostacyclin in the pathogenesis of thrombosis is still controversial, however. ${ }^{11-13}$ On the other hand, some investigators suggested that the neutralis- ation of phospholipid might result in reduced activation of protein $C$, which could be responsible for the occurrence of thrombotic complications in a proportion of patients with the lupus anticoagulant. ${ }^{914} 15$

In an attempt to clarify the pathogenesis of the thrombosis associated with the lupus anticoagulant we compared patients with systemic lupus erythematosus with and without the anticoagulant for factors of coagulation and fibrinolysis, and prostacyclin production by cultured aortic endothelial cells, all of which were measured simultaneously.

\section{Patients and methods}

PATIENTS

One hundred and six Japanese patients with systemic lupus erythematosus (six men, 100 women) were studied for the presence of the lupus anticoagulant. All patients fulfilled the 1982 revised criteria for classification of systemic lupus erythematosus by the American Rheumatism Association. ${ }^{16}$ Patients with active lupus nephritis were not included in the study as this might have affected some of the factors associated with haemostasis. ${ }^{17} 18$ The APTT was determined by a mixing test to screen for lupus anticoagulant activity. Concentrations of fibrinopeptides $A$ and $B_{815-42}, D$ dimer, platelet factor $4, \beta$ thromboglobulin, 6-keto-prostaglandin $F_{1 \alpha}$, thromboxane $B_{2}$, protein $C$, antithrombin III, plasminogen, and serum stimulatory activity on prostacyclin production by cultured aortic endothelial cells were studied in six to 10 patients with and without the lupus anticoagulant. Patients in the two groups were matched for sex, age, and the dose of prednisolone. Except for prednisolone, all drugs were withdrawn seven days before the start of the study.

SCREENING FOR LUPUS ANTICOAGULANT ACTIVITY Lupus anticoagulant was detected by prolongation of a mixing test for APTT, using the 1:5 diluted APTT reagent (Automated APTT, General Diagnostics), according to the method of Colaco and Elkon, ${ }^{19}$ the mixture being $(1: 1)$ for normal and patient plasma. Prolongation of the mixed plasma APTT by more than 10 seconds compared with normal plasma was considered to indicate the presence of lupus anticoagulant.

ASSAY OF ANTICARDIOLIPIN ANTIBODIES

Serum anticardiolipin antibodies were measured 
by an enzyme linked immunosorbent assay (ELISA), according to the procedure described by Ishii et al. ${ }^{20}$ The values of IgG anticardiolipin antibodies were expressed as units compared with the value for standard serum. A positive result ( $>25$ units) indicated a value in units more than three SD above the mean value obtained with control serum samples (106 healthy volunteers).

COAGULATION AND FIBRINOLYSIS FACTOR ASSAYS Plasma concentrations of fibrinopeptides $A$ and $B_{15-42}$ were measured by radioimmunoassay kits (Imco, Sweden). ${ }^{21}{ }^{22}$ Plasma concentrations of $\mathrm{D}$ dimer were assayed by an enzyme linked immunoassay using a kit (MAbCo, Australia). Plasma concentrations of platelet factor 4 and $\beta$ thromboglobulin were measured with radioimmunoassay kits (Dainabot and Amersham). Peripheral plasma 6-keto-prostaglandin $F_{1 \alpha}$ and thromboxane $B_{2}$ were assayed by radioimmunoassay kits (polyethylene glycol method; New England Nuclear). Plasma concentrations of protein $\mathrm{C}$ antigen were measured by electroimmunoassay, using antiprotein C serum (American Diagnostica) ${ }^{23}$ Plasma antithrombin III and plasminogen were measured spectrophotometrically by recording the absorbance change at $\mathbf{4 0 5} \mathrm{nm}$, using $p$-nitroanilide (Daiichi Pure Chemicals, Japan). ${ }^{24}$

\section{ASSAY OF PROSTACYCLIN (PROSTAGLANDIN}

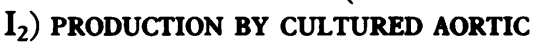

ENDOTHELIAL CELLS

Endothelial cells were scraped off from the intima of the thoracic aorta of a one year old calf and were cultured in Dulbecco's modified Eagle's medium supplemented with $100 \mu \mathrm{g} / \mathrm{ml}$ gentamycin and $10 \%$ fetal calf serum. When confluent, the cells were passaged by trypsinis- ation with $0.05 \%(w / v)$ trypsin solution. Prostacyclin production was determined when the cells reached monolayered confluence. After removal of the medium, Dulbecco's modified Eagle's medium containing $10 \%$ plasma derived serum, obtained by centrifugation and recalcification of patients' plasma was added and the preparation incubated for one hour at $37^{\circ} \mathrm{C}$. The medium was removed and used for assay of 6keto-prostaglandin $F_{1 \alpha}$ (the stable breakdown production of prostaglandin $I_{2}$ ) by radioimmunoassay using a kit obtained from New England Nuclear (Boston, Mass). ${ }^{25} 26$

\section{STATISTICAL ANALYSIS}

Data were analysed with Student's unpaired $t$ test.

\section{Results}

The lupus anticoagulant was detected in $\mathbf{1 7}$ (two men, 15 women) of 106 patients with systemic lupus erythematosus $(16 \%)$. Ten $(59 \%)$ of these 17 patients, but only five of 89 patients (6\%) without the lupus anticoagulant, had a history of thrombosis $(p<0.01)$. It should be noted that cerebral infarctions were present in six $(35 \%)$ patients with the lupus anticoagulant in contrast with (1\%) without the anticoagulant $(p<0.01)$. All the patients with lupus anticoagulant had high titres of anticardiolipin antibodies, and six of $17(35 \%)$ patients with the anticoagulant had thrombocytopenia (table 1). Recurrent fetal loss was found in four of 11 multigravida with the lupus anticoagulant (Nos $1,4,11,13$ ).

Table 2 provides a comparison of haemostatic factors in patients with systemic lupus erythematosus with and without the anticoagulant. Concentrations of fibrinopeptides $A$ and $B_{\beta 15-42}$ were significantly higher in the lupus patients

Table 1 Thromboembolic complications in patients with the lupus anticoagulant

\begin{tabular}{|c|c|c|c|c|c|c|c|}
\hline $\begin{array}{l}\text { Patient } \\
\text { No }\end{array}$ & $\begin{array}{l}\text { Age } \\
\text { (years) }\end{array}$ & Sex & $\underset{(s)}{A P T T^{*}}$ & $\begin{array}{l}\text { Diluted } \\
\text { APTTt (s) }\end{array}$ & $\underset{\text { (units) }}{a C L^{*}}(I g G) t$ & $\begin{array}{l}\text { Platelets } \\
\left(\times 10^{9} / l\right)\end{array}$ & Clinical features $\neq$ \\
\hline 1 & 38 & $\mathbf{F}$ & $48 \cdot 9$ & $83 \cdot 6$ & 58 & 94 & \multirow{8}{*}{$\begin{array}{l}\text { Cerebral infarction (recent), right central } \\
\text { retinal artery thrombosis (recent), right } \\
\text { renal infarction (old) } \\
\text { Cerebral infarction (recent), right renal } \\
\text { infarction (old) } \\
\text { Myocardial infarction (recent), cerebral } \\
\text { infarction (old) } \\
\text { Peripheral retinal artery thrombosis (after) } \\
\text { Cerebral infarction (old), right central } \\
\text { retinal artery thrombosis (old) } \\
\text { Cerebral infarction (old) } \\
\text { Transient ischaemic attack (old), } \\
\text { thrombophlebitis of the leg (old) }\end{array}$} \\
\hline 2 & 19 & $\mathbf{F}$ & $37 \cdot 9$ & $63 \cdot 2$ & 115 & 185 & \\
\hline 3 & 58 & $\mathbf{M}$ & $57 \cdot 3$ & $118 \cdot 1$ & 27 & 164 & \\
\hline $\begin{array}{l}4 \\
5\end{array}$ & $\begin{array}{l}39 \\
41\end{array}$ & $\begin{array}{l}\mathbf{F} \\
\mathbf{F}\end{array}$ & $\begin{array}{l}46 \cdot 3 \\
38 \cdot 2\end{array}$ & $\begin{array}{l}77 \cdot 9 \\
49 \cdot 1\end{array}$ & $\begin{array}{l}155 \\
130\end{array}$ & $\begin{array}{l}113 \\
166\end{array}$ & \\
\hline $\begin{array}{l}6 \\
7\end{array}$ & $\begin{array}{l}46 \\
48\end{array}$ & $\begin{array}{l}\mathbf{F} \\
\mathbf{F}\end{array}$ & $\begin{array}{l}35 \cdot 4 \\
40 \cdot 6\end{array}$ & $\begin{array}{l}48 \cdot 6 \\
57 \cdot 6\end{array}$ & $\begin{array}{r}80 \\
130\end{array}$ & $\begin{array}{l}206 \\
258\end{array}$ & \\
\hline $\begin{array}{r}8 \\
9 \\
10 \\
11\end{array}$ & $\begin{array}{l}20 \\
35 \\
47 \\
34\end{array}$ & $\begin{array}{l}\mathbf{F} \\
\mathbf{F} \\
\mathbf{F} \\
\mathbf{F}\end{array}$ & $\begin{array}{l}37 \cdot 2 \\
42 \cdot 8 \\
42 \cdot 4 \\
40 \cdot 5\end{array}$ & $\begin{array}{l}57.9 \\
60.8 \\
61.0 \\
59.0\end{array}$ & $\begin{array}{r}135 \\
39 \\
60 \\
380\end{array}$ & $\begin{array}{r}139 \\
138 \\
297 \\
40\end{array}$ & \\
\hline $\begin{array}{l}12 \\
13 \\
14 \\
15 \\
16 \\
17\end{array}$ & $\begin{array}{l}42 \\
30 \\
40 \\
36 \\
49 \\
23\end{array}$ & $\begin{array}{l}\mathbf{F} \\
\mathbf{F} \\
\mathbf{F} \\
\mathbf{M} \\
\mathbf{F} \\
\mathbf{F}\end{array}$ & $\begin{array}{r}103 \cdot 2 \\
35 \cdot 1 \\
34 \cdot 9 \\
49 \cdot 7 \\
33 \cdot 7 \\
41 \cdot 7\end{array}$ & $\begin{array}{r}196 \cdot 2 . \\
49 \cdot 8 \\
54 \cdot 2 \\
87.4 \\
50 \cdot 9 \\
55 \cdot 4\end{array}$ & $\begin{array}{r}1000 \\
30 \\
39 \\
130 \\
210 \\
114\end{array}$ & $\begin{array}{r}82 \\
52 \\
184 \\
82 \\
227 \\
198\end{array}$ & \\
\hline Normal & & & $29.8(1.9) \|$ & $\|35.5(3.4)\|$ & $\leqslant 25$ & $125-375$ & \\
\hline
\end{tabular}

${ }^{*}$ APTT = activated partial thromboplastin time; $\mathrm{aCL}=$ anticardiolipin antibodies.

*APTT = activated partial thromboplastin time; aCL
tDetails given in 'Patients and methods' section.

tDetails given in 'Patients and methods' section.
fRecent $=$ the lupus anticoagulant was examined within two weeks from the time when the thrombosis occurred; old=the fRecent $=$ the lupus anticoagulant was examined within two weeks from the time when the thrombosis occurred; old=the
lupus anticoagulant was examined more than two months after the thrombosis occurred; after=thrombosis occurred two months lupus anticoagulant was examined more than
after the lupus anticoagulant was examined.

|Values are mean (SD). 
Table 2 Haemostatic factors in patients with systemic lupus erythematosus with and without the lupus anticoagulant. Values are shown as mean $(S D)$

\begin{tabular}{|c|c|c|c|c|c|c|}
\hline $\begin{array}{l}\text { Factor } \\
\text { Fibrinopeptide A (ng/ml) }\end{array}$ & \multirow{2}{*}{$\begin{array}{l}\begin{array}{l}\text { Normal } \\
\text { value }\end{array} \\
0 \cdot 5-2 \cdot 0 \\
0 \cdot 7-4 \cdot 8 \\
<150 \\
<20 \\
<50 \\
12-33 \\
14-50 \\
69-134 \\
79-121 \\
75-125\end{array}$} & \multicolumn{2}{|c|}{$\begin{array}{l}\text { Lupus anticoagulant } \\
(-)\end{array}$} & \multicolumn{2}{|c|}{$\begin{array}{l}\text { Lupus anticoagulant } \\
(+)\end{array}$} & \multirow{2}{*}{$\begin{array}{l}p \text { Value } \\
<0.05 \\
<0.05 \\
\text { NS } \\
\text { NS } \\
\text { NS } \\
\text { NS } \\
\text { NS } \\
\text { NS } \\
\text { NS } \\
\text { NS }\end{array}$} \\
\hline $\begin{array}{l}\text { Fibrinopeptide A (ng/ml) } \\
\text { Fibrinopeptide } B_{\beta 15-42}(\mathrm{ng} / \mathrm{ml}) \\
\text { D dimer (ng/ml) } \\
\text { Platelet factor } 4(\mathrm{ng} / \mathrm{ml}) \\
\beta \text { Thromboglobulin }(\mathrm{ng} / \mathrm{ml}) \\
\text { 6-Keto-prostaglandin } \mathrm{F}_{\mathrm{la}}(\mathrm{pg} / \mathrm{ml}) \\
\text { Thromboxane } \mathrm{B}_{2}(\mathrm{pg} / \mathrm{ml}) \\
\text { Protein C (\%) } \\
\text { Antithrombin III (\%) } \\
\text { Plasminogen (\%) }\end{array}$ & & $\begin{aligned} 2 \cdot 7(3 \cdot 1) \\
4 \cdot 4(2 \cdot 0) \\
119(59) \\
8 \cdot 5(11) \\
29(35) \\
10 \cdot 3(6 \cdot 6) \\
18 \cdot 8(6 \cdot 5) \\
129(22) \\
111(13) \\
77 \cdot 8(20 \cdot 0)\end{aligned}$ & $\begin{array}{l}(\mathbf{n}=9) \\
(\mathbf{n}=9) \\
(\mathbf{n}=9) \\
(\mathbf{n}=6) \\
(\mathbf{n}=6) \\
(\mathbf{n}=6) \\
(\mathbf{n}=6) \\
(\mathbf{n}=6) \\
(\mathbf{n}=6) \\
(\mathbf{n}=6)\end{array}$ & $\begin{array}{l}20 \cdot 2(29 \cdot 5) \\
11 \cdot 9(12 \cdot 7) \\
123(69) \\
5 \cdot 2(1 \cdot 3) \\
66(78) \\
16 \cdot 7(3 \cdot 9) \\
97(105) \\
94(20) \\
101(18) \\
81 \cdot 3(5 \cdot 3)\end{array}$ & $\begin{array}{l}(\mathbf{n}=10) \\
(\mathbf{n}=10) \\
(\mathbf{n}=8) \\
(\mathbf{n}=6) \\
(\mathbf{n}=6) \\
(\mathbf{n}=6) \\
(\mathbf{n}=6) \\
(\mathbf{n}=6) \\
(\mathbf{n}=6) \\
(\mathbf{n}=6)\end{array}$ & \\
\hline
\end{tabular}

with the anticoagulant than in those without (fibrinopeptide A 20.2 SD (29.5) $v 2.7$ (3.1) $\mathrm{ng} / \mathrm{ml}, \mathrm{p}<0.05$; fibrinopeptide $B_{\beta 15-42} 11.9$ $(12.7)$ v $4.4(2.0) \mathrm{ng} / \mathrm{ml}, \mathrm{p}<0.05)$. Concentrations of $\mathrm{D}$ dimer and platelet factor 4 were not significantly different in those with and without the lupus anticoagulant. Although the mean values of $\beta$ thromboglobulin and thromboxane $B_{2}$ in patients with the lupus anticoagulant were higher than in those without, the difference was not statistical. Concentrations of 6-keto-prostaglandin $F_{1 \alpha}$, protein $C$, antithrombin III, and plasminogen were not significantly different in those with and without the lupus anticoagulant.

Table 3 lists the plasma concentrations of coagulation associated factors in 10 patients with the lupus anticoagulant. Fibrinopeptides $A$ and $B_{\beta 15-42}$ in three patients with the lupus anticoagulant with a recent thrombosis were higher than normal. Those with old thrombosis or those with no thrombosis showed no increase of plasma fibrinopeptide A, except for patient No 5 . The concentration of fibrinopeptide $B_{\beta 15-42}$ were slightly increased in five patients with the lupus anticoagulant without a recent thrombosis. In patients with a recent thrombosis (Nos 1 and 2) concentrations of $D$ dimer and thromboxane $B_{2}$ were high, whereas the values of 6-keto-prostaglandin $F_{1 \alpha}$ were normal in all but one patient (No 2).

The figure shows the serum stimulatory activity on prostaglandin $I_{2}$ production by cultured aortic endothelial cells in vitro. Although the activity in patients with the lupus anticoagulant was widely distributed compared with that in patients without it, there was no significant difference (6-keto-prostaglandin $F_{10}$ 351 (SD 82) v 388 (39) $\mathrm{pg} / 10^{4}$ cells/hour). It should be noted, however, that serum samples from two patients with the lupus anticoagulant

Table 3 Haemostatic factors in patients with the lupus anticoagulant

\begin{tabular}{|c|c|c|c|c|c|c|}
\hline $\begin{array}{l}\text { Patient } \\
\mathrm{No}^{*}\end{array}$ & $\begin{array}{l}\text { FPAt } \\
(n g / m l)\end{array}$ & $\begin{array}{l}F P B_{\beta j S-12} t \\
(n g / m l)\end{array}$ & $\begin{array}{l}D \text { dimer } \\
(n g / m l)\end{array}$ & $\begin{array}{l}T X B_{2} f \\
(p g / m l)\end{array}$ & $\begin{array}{l}\text { 6-Keto-PGF }{ }_{\text {lut }} \\
(\mathrm{pg} / \mathrm{ml})\end{array}$ & Thrombosisf \\
\hline $\begin{array}{r}1 \\
2 \\
3 \\
4 \\
5 \\
6 \\
7 \\
8 \\
9 \\
10\end{array}$ & $\begin{array}{r}6.9 \\
46.9 \\
82 \cdot 7 \\
10 \cdot 3 \\
52.2 \\
0.7 \\
1.4 \\
0.2 \\
0.6 \\
0.5\end{array}$ & $\begin{array}{c}43 \\
6 \cdot 2 \\
24 \cdot 9 \\
4 \cdot 9 \\
13 \\
7 \cdot 8 \\
7 \cdot 1 \\
4 \cdot 3 \\
6 \cdot 0 \\
4 \cdot 2\end{array}$ & $\begin{array}{r}248 \\
176 \\
\text { NDt } \\
53 \\
\text { ND } \\
54 \\
53 \\
156 \\
30 \\
137\end{array}$ & $\begin{array}{r}170 \\
280 \\
\text { ND } \\
27 \\
31 \\
\text { ND } \\
\text { ND } \\
52 \\
\text { ND } \\
23\end{array}$ & $\begin{array}{l}21 \\
11 \\
\text { ND } \\
13 \\
19 \\
\text { ND } \\
\text { ND } \\
19 \\
\text { ND } \\
17\end{array}$ & $\begin{array}{l}+ \text { (recent) } \\
+ \text { (recent) } \\
+ \text { (recent) } \\
+ \text { (after) } \\
+ \text { (old) } \\
+ \text { (old) } \\
+ \text { (old) } \\
= \\
-\end{array}$ \\
\hline Normal & $0.5-2 \cdot 0$ & $0 \cdot 7-4 \cdot 8$ & $<150$ & $14-50$ & $12-33$ & \\
\hline
\end{tabular}

*The patient numbers correspond with those in table 1 .

†FPA = fibrinopeptide $A ; \mathrm{FPB}_{\beta 15-42}=$ fibrinopeptide $\mathrm{B}_{\beta 15-12} ; \mathrm{TXB}_{2}=$ thromboxane $\mathrm{B}_{2} ;$ 6-keto$\mathrm{PGF}_{1 \alpha}=6-$ keto-prostaglandin $\mathrm{F}_{1 a} ; \mathrm{ND}=$ not done.

¥Explanations for recent, after, and old given in footnote to table 1 .

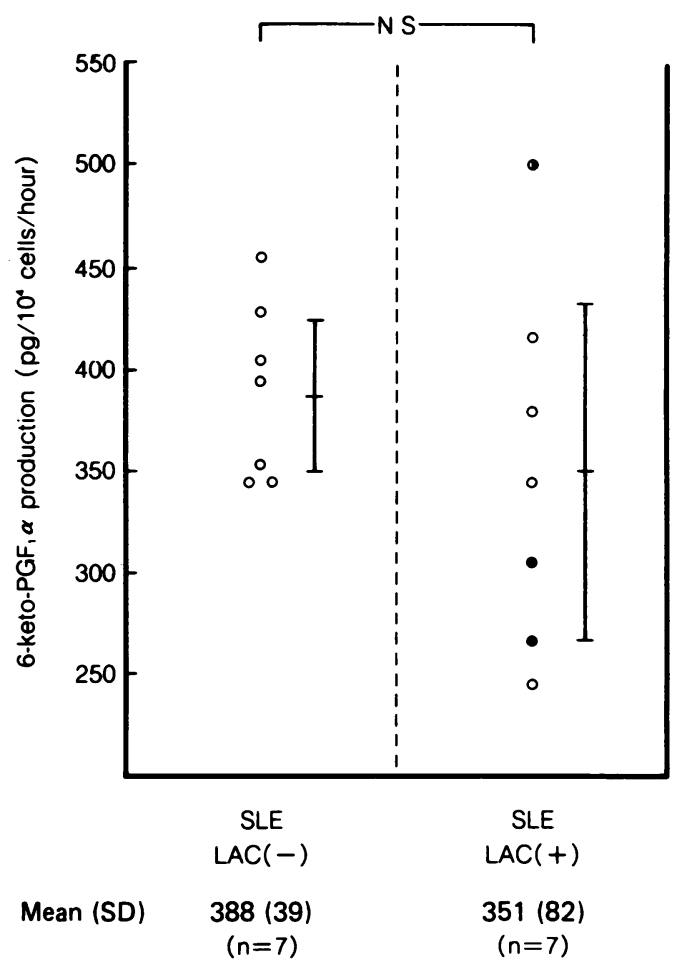

6-Keto-prostaglandin $F_{l \alpha}(6-$ keto-PGF $)$ production by cultured bovine aortic endothelial cells by platelet poor, plasma derived serum from patients with systemic lupus erythematosus. $L A C=$ lupus anticoagulant; $\mathrm{O}=a$ patient without thrombosis. =a patient who has recent (within two weeks) thrombosis. $\mathbf{O}=$ a patient with an old (more than two months) thrombosis.

who had recently had thrombosis inhibited 6-keto-prostaglandin $F_{1 \alpha}$ production to concentrations more than 2 SD below the mean.

\section{Discussion}

We detected the lupus anticoagulant in 17 (16\%) of 106 patients with systemic lupus erythematosus, a prevalence similar to that previously reported. ${ }^{27}$ The incidence of thrombosis in patients with the lupus anticoagulant reached $59 \%$, which is higher than results noted by other workers. ${ }^{28}$ Our results strongly suggest that the presence of lupus anticoagulant is associated with the occurrence of thrombosis. It is not clear why thrombosis occurs more commonly in patients with this anticoagulant, however.

Fibrinopeptide A and D dimer reflect activation of blood coagulation, and fibrinopeptide $\mathrm{B}_{\beta 15-42}$ is related to fibrinolysis. ${ }^{29-31}$ These factors can be expected to be markers predictive of thrombosis. As the value of fibrinopeptide $A$ 
was increased only in patients with the lupus anticoagulant with a recent thrombosis, except for patient No 5 (table 3), assay of fibrinopeptide $A$ is useful to predict a thrombosis. Concentrations of fibrinopeptide $B_{\beta 15-42}$ were slightly increased even in patients without recent thrombosis, however, thus it may be less specific than fibrinopeptide $\mathbf{A}$ for a thrombosis linked to lupus anticoagulant. Because the increase in fibrinopeptide A was confined to patients with a recent thrombosis (except for patient No 5) and clinical signs of thrombosis were not seen in all patients with the lupus anticoagulant, only a certain proportion of patients with the anticoagulant seemed to be at risk for thrombosis.

Although there was no significant difference in the concentrations of thromboxane $B_{2}$ between patients with and without the lupus anticoagulant, these concentrations were remarkably increased in the two patients with anticoagulant who had recently had a cerebral infarction-a similar phenomenon to that found with fibrinopeptide $A$. Since thromboxane $B_{2}$ is a stable catabolite of thromboxane $A_{2}$, which induces platelet aggregation and vasoconstriction, ${ }^{32}$ the increase of thromboxane $B_{2}$ may enhance thromboembolism and serve for a marker related to the initiation or evolution of thrombosis.

6-Keto-prostaglandin $F_{1 \alpha}$ is a non-enzymatic degradation product of prostacyclin (prostaglandin $\mathrm{I}_{2}$ ) which inhibits platelet aggregation and opposes the constrictor effects of platelet release products on the vessel wall, resulting in control of thrombus formation. ${ }^{68}$ Carreras et al showed that the IgG fraction, which contains the lupus anticoagulant, reduced the in vitro release of prostaglandin $I_{2}$ from rat aorta rings or pregnant human myometrium and postulated that the anticoagulant might interfere with the release of arachidonic acid (substrate for the production of prostaglandin $\mathrm{I}_{2}$ ) from phospholipids in the cell membrane. ${ }^{68}$ They also noted a patient with the lupus anticoagulant with reduced concentrations of plasma 6-keto-prostaglandin $F_{1 \alpha}{ }^{6}$ We found only one patient with a slightly reduced concentration of plasma 6keto-prostaglandin $F_{1 \alpha}$ in six patients with the lupus anticoagulant. On the other hand, the in vitro study showed that the serum derived from plasma from two patients who had recently had thrombosis and who had high concentrations of plasma fibrinogens $A$ and $B_{\beta 15-42}$ had decreased stimulatory activity on prostaglandin $I_{2}$ production, though there was no statistical difference in this production between lupus patients with or without the anticoagulant. Such an inhibitory activity was found in eight of 14 patients by Carreras $^{8}$ and in four of seven by Elias. ${ }^{34}$ In contrast, Cariou et al found no inhibition of prostaglandin $I_{2}$ production by patients' $I g G,{ }^{15}$ and Hasselaar et al concluded that, in general, interference of antiphospholipid antibodies with endothelial prostanoid synthesis did not explain the thrombosis. ${ }^{13}$ Thus the number of patients with the lupus anticoagulant who have an inhibitory activity on prostaglandin $I_{2}$ production may be considerably limited.

Protein C deficiency, decreased antithrombin
III activity, and low concentrations of functional plasminogen have been reported to be predictive of thromboembolism. ${ }^{29}$ In our study, however, the concentrations of those factors did not differ between lupus patients with or without the anticoagulant. Freyssinet et al showed that the anticoagulant fraction from patients' plasma was able to neutralise the positive effect of phospholipids in the activation of protein $\mathrm{C}$ by the thrombin-thrombomodulin complex. They suggested that reduced activation of protein $\mathrm{C}$ might be responsible for the occurrence of thrombotic complications in a proportion of patients with the lupus anticoagulant. ${ }^{9}$ We could not confirm this suggestion as the concentration of plasma protein $C$ was not decreased in our study. Recently, however, Alarcón-Segovia and Sanchez-Guerrero reported that at least two of their patients with primary antiphospholipid syndrome showed reduced activity of protein $\mathrm{C}$, although possessing normal antigenic amounts of it. ${ }^{14}$

From this study we draw two tentative conclusions. Firstly, measurement of the plasma concentrations of fibrinopeptide $A$ and thromboxane $B_{2}$ is useful to predict thrombosis in lupus patients with the anticoagulant, and some antithrombotic treatment will be necessary for patients with high concentrations of fibrinopeptide $A$ and thromboxane $B_{2}$, though not all patients with the lupus anticoagulant are in a hypercoagulable state. Secondly although the pathogenesis of thrombosis in patients with lupus anticoagulant is still unclear, serum inhibition of prostaglandin $I_{2}$ production by the endothelial cells may occur in only some patients with the anticoagulant. The pathogenesis of the thrombotic events may be multifactorial and several subsets of patients may exist.

1 Yin E T, Gaston L W. Purification and kinetic studies on a circulating anticoagulant in a suspected case of lupus 14: 88-115.

2 Feinstein D I, Rapaport S I. Acquired inhibitors of blood coagulation. Prog Hemost Thromb 1972; 1: 75-95.

3 Hughes G R V. Thrombosis, abortion, cerebral disease, and the lupus anticoagulant. $B M \mathcal{F} 1983 ; 287$ : 1088-9.

4 Feinstein D I. Lupus anticoagulant, thrombosis, and feta loss. N Engl f Med 1985; 21: 1348-50.

5 Glueck H I, Kant K S, Weiss M A, Pollak V E, Miller M A Coots $M$. Thrombosis in systemic lupus erythematosus. Arch Intern Med 1985; 145: 1389-95.

6 Carreras L O, Defreyn G, Machin S J, et al. Arterial thrombosis, intrauterine death and "lupus" anticoagulant. Detection of immunoglobulin interfering with prostacyclin Detection of immunoglobulin inter

7 Angles-Cano E, Sultan Y, Clauvel J-P. Predisposing factors to thrombosis in systemic lupus erythematosus. Possible relation to endothelial cell damage. $\mathcal{F}$ Lab Clin Med 1979 94: 312-23.

8 Carreras L O, Vermylen J G. "Lupus" anticoagulant and thrombosis-possible role of inhibition of prostacyclin formation. Thromb Haemost 1982; 48: 38-40.

9 Freyssinet J M, Wiesel M L, Gauchy J, Boneu B, Cazenave J P. An IgM lupus anticoagulant that neutralizes the enhancing effect of phospholipid on purified endothelial thrombomodulin activity-a mechanism for thrombosis. Thromb Haemost 1986; 55: 309-13.

10 Francis R B Jr, McGehee W G, Feinstein D I. Endothelialdependent fibrinolysis in subjects with the lupus anticoagulant and thrombosis. Thromb Haemost 1988; 59: coagulant

11 Rustin M H A, Bull H A, Machin S J, Isenberg D A, Snaith M L, Dowd P M. Effects of the lupus anticoagulant in M L, Dowd P M. Effects of the lupus anticoagulant in patients with systemic lupus erythematosus on endothelial
cell prostacyclin release and procoagulant activity. $\mathcal{F}$ Invest cell prostacyclin release and

12 Asherson R A, Harris E N, Hughes G R V, Ritter J M, Barrow S E, Jones M. Prostacyclin in systemic lupus and anticardiolipin syndrome. Ann Rhewn Dis 1987; 46: 422-3. 
13 Hasselaar P, Derksen R H W M, Blokzijl L, de Groot P G. Thrombosis associated with antiphospholipid antibodies cannot be explained by effects of endothelial and platelet prostanoid synthesis. Thromb Haemost 1988; 59: 80-5.

14 Alarcón-Segovia D, Sanchez-Guerrero J. Primary antiphospholipid syndrome. F Rheumatol 1989; 16: 482-8.

15 Cariou R, Tobelem G, Bellucci S, et al. Effect of lupus anticoagulant on antithrombogenic properties of endothelial cells-inhibition of thrombomodulin-dependent protein C activation. Thromb Haemost 1988; 60: 54-8.

16 Tan E M, Cohen A S, Fries J F, et al. The 1982 revised criteria for the classification of systemic lupus erythematosus. Arthritis Rhewem 1982; 25: 1271-7.

17 Tomura S, Oono Y, Kuriyama R, Takeuchi J. Plasma concentrations of fibrinopeptide $A$ and fibrinopeptide $B 15$. 42 in glomerulonephritis and the nephrotic syndrome. Arch Intern Med 1985; 145: 1033-5.

18 Cronlund M, Hardin J, Burton J, Lee L, Haber E, Bloch K $J$. Fibrinopeptide $A$ in plasma of normal subjects and patients with disseminated intravascular coagulation and systemic lupus erythematosus. I Clin Invest 1976; 58: 142-51.

19 Colaco C B, Elkon K B. The lupus anticoagulant. Arthritis Rhewom 1985; 28: 67-74.

20 Ishii Y, Nagasawa K, Mayumi T, Niho Y. Clinical importance of persistence of anticardiolipin antibodies in systemic lupus erythematosus. Ann Rhewn $D$ is 1990; 49: $387-90$

21 Hofmann V, Straub P W. A radioimmunoassay technique for the rapid measurement of human fibrinopeptide $A$. Thromb Res 1977; 1: 171-81.

22 Kudryk B, Robinson D, Netré C, Hessel B, Blombäck M, Blombäck $B$. Measurement in human blood of fibrinogen fibrin fragments containing the B $\beta$ 15-42 sequence. Thromb Res 1982; 25: 277-91.

23 Bertina R M, Broekmans A W, van der Linden I K, Mertens $K$. Protein C deficiency in a Dutch family with thrombotic disease. Thromb Haemost 1982; 48: 1-5.
24 Friberger P, Knös M, Gustavsson S, Aurell L, Claeson G Methods for determination of plasmin, antiplasmin and plasminogen by means of substrate S-2251. Haemostasis 1978; 7: 138-45.

25 Inoguchi T, Umeda F, Watanabe J, Ibayashi H. Reduced serum-stimulatory activity on prostacyclin production by cultured aortic endothelial cells in diabetes mellitus. Haemostasis 1986; 16: 447-52.

26 Inoguchi T, Umeda F, Watanabe J, Ibayashi H. Stimulatory activity on prostacyclin production decreases in sera from activity on prostacyclin production decreases in sera from Pract 1987; 3: 243-8.

27 Gastineau D A, Kazmier F J, Nichols W L, Bowie E J W Lupus anticoagulant: an analysis of the clinical and laboratory features of 219 cases. Am $\mathcal{F}$ Hematol 1985; 19: 265-75.

28 Lechner K, Pabinger-Fasching I. Lupus anticoagulants and thrombosis: a study of 25 cases and review of the literature. Haemostasis 1985; 15: 254-62.

29 Hirsh J. Laboratory diagnosis of thrombosis. In: Colman $R$ W, Hirsh J, Marder V J, Salzman E W, eds. Hemostasis and thrombosis. Philadelphia: Lippincott, 1987: 1165-83.

30 Nossel H L. Relative proteolysis of the fibrinogen B $\beta$ chain by thrombin and plasmin as a determinant of thrombosis. by thrombin and plasmin

31 Mombelli G, Im Hof V, Haeberli A, Straub P W. Effect of heparin on plasma fibrinopeptide $A$ in patients with acute myocardial infarction. Circulation 1984; 69: 684-9.

32 Ellis E F, Oelz O, Roberts L J, et al. Coronary arteria smooth muscle contraction by a substance released from platelets: evidence that it is thromboxane $A_{2}$. Science 1976 193: 1135-7.

33 Tada M, Hoshida S, Kuzuya T, Inoue M, Minamino T, Abe $H$. Augmented thromboxane $A_{2}$ generation and efficacy of its blockade in acute myocardial infarction. Int 7 Cardiol 1985; 8: 301-12.

34 Elias M, Eldor A. Thromboembolism in patients with the 'lupus'-type circulating anticoagulant. Arch Intern Med 1984; 144: 510-5. 